\title{
Coexistence of anemia and vitamin A deficiency in women of childbearing age in the Northeast region of Brazil ${ }^{1}$
}

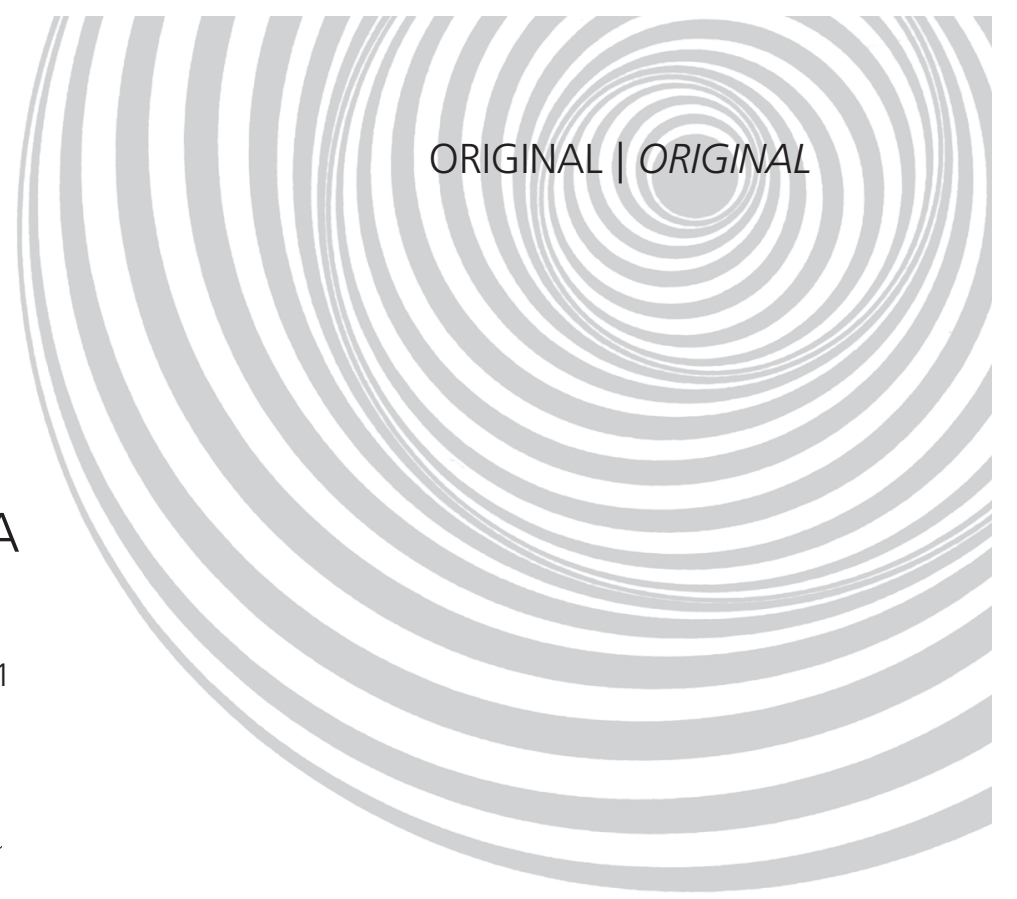

\section{Coexistência de anemia e deficiência de}

\author{
vitamina A em mulheres em idade
}

fértil no Nordeste do Brasil

Manuela Hazin COSTA ${ }^{2}$

Ariani Impieri de SOUZA ${ }^{3}$

Maria Cynthia BRAGA ${ }^{3}$

Malaquias BATISTA FILHO

A B S T R A C T

\section{Objective}

The aim of this study was to investigate the association between anemia and vitamin A deficiency in women of childbearing age in Pernambuco, a state in the Brazilian Northeast.

\section{Methods}

A cross-sectional study was conducted making a secondary database analysis of "The Third State Survey on Health and Nutrition" done from May to September 2006. Data were collected from 761 women of childbearing age (10-49 years).

\section{Results}

The simultaneous occurrence of the two deficiencies was found in only seven women $(0.9 \%)$. The prevalence of anemia was of $15.1 \%$, and of vitamin A deficiency, $8.2 \%$. There was no association between the two conditions $(p=0.380)$, although a positive correlation was found between retinol levels and hemoglobin concentration $(r=0.13)$.

\section{Conclusion}

Anemia and vitamin A deficiency did not coexist. Anemia was considered a mild public health problem, while vitamin A deficiency was not considered an epidemiological problem.

Indexing terms: Anemia. Vitamin A deficiency. Women.

1 Article developed as part of the MH COSTA, intitled "Anemia e hipovitaminose A em mulheres em idade fértil no estado de Pernambuco: relações recíprocas e fatores associados”. Instituto de Medicina Integral Prof. Fernando Figueira; 2011.

2 Universidade Federal de Pernambuco, Departamento de Clínica Médica, Disciplina de Hematologia. Recife, PE, Brasil.

3 Instituto de Medicina Integral Prof. Fernando Figueira, Programas de Pós-Graduação em Saúde Materno-Infantil. R. dos Coelhos, 300, Boa Vista, 50070-550, Recife, PE, Brasil. Correspondência para/Correspondence to: AI SOUZA. E-mail: <ariani@imip.org.br>. 
510 | MH COSTA et al.

\section{RE S U M O}

\section{Objetivo}

O objetivo deste trabalho foi avaliar a prevalência da associação entre anemia e deficiência de vitamina A em mulheres em idade fértil em Pernambuco.

\section{Métodos}

Foi realizado estudo transversal com análise secundária do banco de dados da "Ill Pesquisa Estadual de Saúde e Nutrição-2006", realizada em Pernambuco, Nordeste do Brasil. Foram selecionados, do banco original, dados das 761 mulheres em idade fértil (10 a 49 anos), excluindo gestantes.

\section{Resultados}

A ocorrência simultânea das duas deficiências foi encontrada em apenas sete mulheres (0,9\%); a prevalência de anemia foi de 15,1\%, e a de deficiência de vitamina $A$, de 8,2\%. Não houve associação entre as duas condições $(p=0,380)$, porém foi observada correlação positiva entre valores de retinol e concentração de hemoglobina $(r=0,13)$.

\section{Conclusão}

Não houve coexistência de anemia e deficiência de vitamina A, e, separadamente, a anemia foi considerada problema de leve magnitude, enquanto a deficiência de vitamina A não chegou a se caracterizar como problema epidemiológico.

Termos de indexação: Anemia. Deficiência de vitamina A. Mulheres.

\section{INTRODUCTION}

Micronutrient deficiency (mainly iron, vitamin $\mathrm{A}$ and iodine) is a leading nutritional problem affecting a large proportion of the world's population manifestly or silently ${ }^{1-3}$. Vitamin A Deficiency (VAD) has historically been a significant problem, especially in developing countries, and even more so in south and southeast Asia, which accounts for more than half of all global VAD cases $^{4,5}$. The only national survey ${ }^{6}$ conducted in Brazil found a VAD prevalence of $12.0 \%$ (retinol $<0.7 \mu \mathrm{mol} / \mathrm{L}$ ) in 2006 , which did not vary significantly by region. The World Health Organization (WHO) considers that the VAD prevalence in women is low at an estimated $2.5 \%^{7}$. On the other hand, the WHO estimates that $50.0 \%$ of women have anemia, mainly pregnant women in developing countries 8 .

There is evidence that anemia reduces the absorption of vitamin $A$ in the intestine and its bioavailability in the body ${ }^{9}$. In turn, VAD affects erythropoiesis and iron metabolism ${ }^{10}$.

An association between VAD and anemia was first reported in the 1920s and 1940s ${ }^{11,12}$. Moreover, poverty, malnutrition, and age may influence the distribution of anemia and VAD in different populations ${ }^{1,6}$.

Public nutrition policies are made globally to address these deficiencies and to reduce healthcare costs ${ }^{13}$. In Brazil, the Ministry of Health recommends iron and vitamin $A$ replacement during pregnancy and postnatally, respectively ${ }^{14,15}$. Ideally, women should have appropriate iron and vitamin A reserves at conception because it is harder to correct these deficiencies during pregnancy, when the maternal and fetal metabolic requirements are higher ${ }^{16}$.

Considering the lack of information about these two nutritional problems in women, the objective of this study was to estimate the prevalence of anemia and VAD, and the coexistence of both, in women of childbearing age in the Brazilian Northeast.

\section{METHODS}

\section{Study design and population}

This paper is a secondary analysis based on the III Pesquisa Estadual de Saúde e Nutricão 
(III PESN-2006, Third State Survey on Health and Nutrition) ${ }^{17}$ done in Pernambuco, state in the Brazilian Northeast, between May and September 2006. Pernambuco has an area of roughly $98,146 \mathrm{~km}^{2}$ and a population of $8,796,032$ inhabitants, of which $51.9 \%$ are women. Mild food insecurity is found in $11.5 \%$ of the households ${ }^{18}$ and $17.6 \%$ of the population over the age of 15 years is illiterate ${ }^{19}$.

There were 801 women available for analysis but 40 pregnant women were excluded, resulting in a sample of 761 women. Given the female population of $4,000,000^{20}$, a prevalence of VAD of $15 \%^{21}$ and of anemia of $20 \%^{8}$, an error of $3 \%$, and a Confidence Interval of $95 \%$ ( $95 \%$ IC), a representative sample would have to have at least 683 women, so the sample above is representative of the women of childbearing age of the state of Pernambuco.

\section{Data source}

The original study aimed to update the health, nutrition, and socioeconomic status data of the population of Pernambuco, focusing on maternal and child health, and to assess the nutritional status and prevalence of anemia and vitamin A deficiency in women aged 10 to 49 years. Sociodemographic data were collected during home visits using a questionnaire.

\section{Anthropometric measurements, collection of blood sample, and blood tests}

The III Perquisa Estadual de Saúde e Nutrição $2006^{17}$ randomly selected a representative sample of the state's urban and rural population. Following the interview, anthropometric measurements (height and weight) were taken and blood samples were collected to determine hemoglobin level and serum retinol. The blood samples for both tests were collected at the local laboratory or at home, when the women could not visit the laboratory.
The participants were asked to fast for 12 hours before blood collection. Hemoglobin level was determined by $\mathrm{HemoCue}^{\odot}$ (immediate reading) using a fingerstick and serum retinol was measured by High Performance Liquid Chromatography $(\mathrm{HPLC})^{22}$. Individuals with hemoglobin level $\leq 12 \mathrm{~g} /$ $\mathrm{dL}$ were considered anemic and with serum retinol $<0.70 \mu \mathrm{mol} / \mathrm{L}$ were considered vitamin-A deficient, as defined by the $\mathrm{WHO}^{7,8}$.

\section{Independent variables}

This study chose the following independent variables: age group ( $<20$ years, 20-34 years, $\geq 35$ years), setting (urban, rural), level of education (incomplete elementary school, elementary school, high school or higher), race (Caucasian, African Brazilian, other), family income in minimum salaries (the Brazilian minimum salary was roughly US $\$ 150.00$ per month in 2006), and nutritional status determined by Body Mass Index (BMI) (<18.5=underweight; 18.5-24.9=normal weight; $25-29.9=$ overweight; $\mathrm{BMI}>30=$ obese).

\section{Statistical treatment}

The data were treated by the software Epi Info version 3.5.1, and STATA version 10.1. The prevalences of anemia, VAD, and their coexistence were calculated, along with their respective 95\% confidence intervals. The frequency distributions of VAD and anemia were described according to sociodemographic and biological characteristics. Proportions were compared by the chi-square test with a significance level of $5 \%$. The correlation between serum retinol and hemoglobin level was investigated by the Pearson correlation coefficient $(r)$.

\section{Study approval}

This study was approved by the Research Ethics Committee of the Instituto de Medicina 
512 | MH COSTA et al.

Integral Prof. Fernando Figueira (IMIP) in Recife, Brazil, under protocol number 1645/2009. All participants of the original study signed a Free and Informed Consent Form.

\section{RE S U L T S}

Of the 761 study women, $49.3 \%$ lived in rural areas and $65.3 \%$ had completed elementary school. Their mean age and Standard Deviation (SD) were $28.5 \pm 6.8$ years and $8.7 \%$ were adolescents (<20 years). Hemoglobin $(\mathrm{Hb})$ level and serum retinol were determined in all but one woman despite all being tested. The prevalence of anemia was 15.1\% (95\% Cl: 12.7-17.8) whereas the prevalence of VAD was $8.2 \%$ (95\% Cl: 6.4-10.3). Table 1 shows the distribution of anemia and VAD according to the sample's sociodemographic and biological characteristics, which did not affect their prevalence.

Anemia and VAD coexisted in 7 women, a prevalence of $0.9 \%(95 \% \mathrm{Cl}: 0.40-1.98)$. Anemia and VAD were not associated $\left(\chi^{2}=0.77\right.$; $p=0.380$ ) (Table 2).

There was a weak, positive correlation between hemoglobin level and serum retinol $(r=0.13, p<0.001)$ (Figure 1).

Table 1. Prevalence of anemia and vitamin A deficiency in women according to sociodemographic and biological factors. Pernambuco (Brazil), 2006

\begin{tabular}{|c|c|c|c|c|c|c|c|c|c|}
\hline \multirow{2}{*}{ Factor } & \multirow{2}{*}{ Total } & \multicolumn{2}{|c|}{ Anemia } & \multirow{2}{*}{$\chi^{2}$} & \multirow{2}{*}{$p$} & \multicolumn{2}{|c|}{ VAD } & \multirow{2}{*}{$\chi^{2}$} & \multirow{2}{*}{$p$} \\
\hline & & $n$ & $\%$ & & & $\mathrm{n}$ & $\%$ & & \\
\hline \multicolumn{10}{|l|}{ Age (years) ${ }^{1}$} \\
\hline$<20$ & 66 & 14 & 21.2 & 3.64 & 0.162 & 3 & 4.5 & 1.30 & 0.522 \\
\hline $20-34$ & 558 & 76 & 13.6 & & & 47 & 8.4 & & \\
\hline$\geq 35$ & 135 & 24 & 17.8 & & & 12 & 8.9 & & \\
\hline \multicolumn{10}{|l|}{ Setting } \\
\hline Rural & 375 & 50 & 13.3 & 1.82 & 0.177 & 33 & 8.8 & 0.43 & 0.509 \\
\hline Urban & 386 & 65 & 16.8 & & & 29 & 7.5 & & \\
\hline \multicolumn{10}{|l|}{ Race $^{1}$} \\
\hline Caucasian & 211 & 27 & 12.8 & 1.07 & 0.584 & 17 & 8.1 & 0.83 & 0.935 \\
\hline African Brazilian & 26 & 5 & 19.2 & & & 2 & 7.7 & & \\
\hline Other & 517 & 82 & 15.9 & & & 43 & 8.3 & & \\
\hline \multicolumn{10}{|l|}{ Education leve/1 } \\
\hline Incomplete elementary school & 518 & 76 & 14.7 & 1.83 & 0.400 & 40 & 7.7 & 0.48 & 0.786 \\
\hline Complete elementary school & 58 & 13 & 22.4 & & & 6 & 10.3 & & \\
\hline Complete high school or higher & 184 & 26 & 14.1 & & & 16 & 8.7 & & \\
\hline \multicolumn{10}{|l|}{ Family income in minimum salaries ${ }^{1}$} \\
\hline$\leq 0.25$ & 410 & 67 & 16.3 & 0.87 & 0.645 & 36 & 8.8 & 1.03 & 0.596 \\
\hline $0.25-0.5$ & 205 & 29 & 14.1 & & & 17 & 8.3 & & \\
\hline$>0.5$ & 133 & 18 & 13.5 & & & 8 & 6.0 & & \\
\hline \multicolumn{10}{|l|}{ Nutritional status ${ }^{1}$} \\
\hline Underweight & 39 & 7 & 17.9 & 3.09 & 0.378 & 3 & 7.7 & 1.19 & 0.754 \\
\hline Normal weight & 382 & 60 & 15.7 & & & 29 & 7.6 & & \\
\hline Overweight & 223 & 36 & 16.1 & & & 21 & 9.4 & & \\
\hline Obese & 113 & 11 & 9.7 & & & 7 & 6.2 & & \\
\hline \multicolumn{10}{|l|}{ First pregnancy ${ }^{1}$} \\
\hline No & 750 & 113 & 15.1 & 0.19 & 0.665 & 60 & 8.0 & 1.89 & 0.169 \\
\hline Yes & 10 & 2 & 20.0 & & & 2 & 20.0 & & \\
\hline
\end{tabular}

Note: ${ }^{1}$ Numbers do not add up because of missing data. VAD: Vitamin A Deficiency. 
Table 2. Association between serum retinol and anemia in women. Pernambuco (Brazil), 2006.

\begin{tabular}{|c|c|c|c|c|c|c|c|}
\hline \multirow{3}{*}{ Retinol ( $\mu \mathrm{mol} / \mathrm{L})$} & \multicolumn{4}{|c|}{ Anemia } & \multirow{3}{*}{ Total } & \multirow{3}{*}{$\chi^{2}$} & \multirow{3}{*}{$p$} \\
\hline & \multicolumn{2}{|c|}{ Yes } & \multicolumn{2}{|c|}{ No } & & & \\
\hline & $n$ & $\%$ & $n$ & $\%$ & & & \\
\hline$\geq 0.70$ (acceptable/normal) & 108 & 15.5 & 591 & 84.5 & 699 & & \\
\hline
\end{tabular}

Note: Source: III Pesquisa Estadual de Saúde e Nutrição (Third State Survey on Health and Nutrition, PESN, 2006).



Figure 1. Correlations between hemoglobin levels and serum retinol. Pernambuco (Brazil), 2006.

\section{DISCUSSION}

The study rates of anemia (15.1\%) and $\operatorname{VAD}(8.2 \%)$ were considered low, in spite of the high economic and social vulnerability of the sample and the low Human Development Index (HDI) of the area ${ }^{19}$. The two conditions, anemia and $V A D$, were present in only seven women, making it a low-magnitude problem.

The prevalence of anemia found by the present study was lower than the prevalence of almost $40 \%$ found by a previous study done in the state of Pernambuco in $1997^{23}$. Once considered a public health problem of moderate prevalence in this state according to the WHO's classification ${ }^{8}$, the prevalence of anemia decreased significantly, now being classified as a problem of mild magnitude (between $5 \%$ and $19.9 \%)$. Remarkably, a study conducted in the Brazilian South, which is wealthier and more developed than the Northeast, found a prevalence of anemia of nearly $20 \%$ in women of childbearing age $^{24}$.

The prevalence of VAD $(8.0 \%)$ is considered a mild problem according to the WHO's classification?. Studies on VAD in women of childbearing age are still scarce in Brazil since most studies include only children and pregnant women $23,25,26$. Therefore, it is not possible to make a comparative analysis. However, the study VAD prevalence seems to be lower than that found by the Pesquisa Nacional de Demografia e Saúde (PNDS, National Demographic and Health Survey) of $2006^{6}$, which found a VAD prevalence of $12.3 \%$ in women of childbearing age.

Although these prevalences are still considered high compared to those of developed countries ${ }^{7,8}$, the low prevalence of anemia and VAD found by this study may be a reflection of the population's better socioeconomic condition. This assumption is reinforced by the fact that only $5 \%$ of the sample was underweight. This finding may also reflect the phenomenon of nutrition transition that occurred in the country in the past decade, characterized by higher rates of obesity and lower rates of malnutrition ${ }^{27}$.

The National Program of Postpartum Vitamin A Supplementation may also help to explain the low VAD prevalence. Pernambuco is included in this program. Women usually receive vitamin A supplements at the public maternity hospital after delivery ${ }^{28}$, but the present study did not verify this information.

Although the coexistence of anemia and VAD was not observed in this study, a positive 
correlation was found between serum retinol and hemoglobin level. This result corroborates other studies that found a positive correlation between hemoglobin level and serum retinol, even though they had not been specifically designed to investigate this correlation and used populations with different characteristics ${ }^{29,30}$. The occurrence of this interaction remains debatable ${ }^{9,10,12,31}$. Some studies found no hematological changes in individuals with retinol deficiency, probably due to the hemoglobin levels of patients with $V A D^{31,32}$, while others showed that vitamin A supplementation improved hemoglobin levels ${ }^{26,33}$.

Anemia diagnosis based on hemoglobin level is one of the limitations of this study because of its limited ability to differentiate iron-deficiency anemia from infectious, hemolytic, and aplastic anemia, among others, or from hemoglobinopathies $^{34}$. Nevertheless, the WHO recommends the use of hemoglobin level as an indicator of anemia in population surveys ${ }^{8}$.

Another limitation of this study is that the original study was designed for other purposes and the number of women with coexistent anemia and VAD was small. These limitations hampered the analysis of an association between the two events in this population, and how they were affected by sociodemographic factors.

Although the study results cannot be generalized to all Brazilians of childbearing age, it raises questions about the actual magnitude of coexistent VAD and anemia. Specifically designed population studies are needed to investigate the association between $\mathrm{VAD}$ and anemia, to estimate the prevalence of this coexistence in different regions of the country, and to determine its physiological mechanisms.

\section{CONCLUSION}

The prevalence of VAD and anemia in the study population was low, and neither one was associated with socioeconomic or biological factors. Anemia was considered a problem of mild significance, while VAD was not characterized as an epidemiological problem. Although a positive correlation was found between hemoglobin level and serum retinol, the coexistence of anemia and VAD was not observed.

\section{A C KNOWLEDGMENTS}

We thank Dr. Pedro Israel Cabral Lira and Prof. José N. Figueroa for their valuable help by providing the III Pesquisa Nacional de Saúde e Nutrição data and helping with the statistical analysis, respectively.

\section{CONTRIBUTORS}

M HAZIN COSTA was responsible for the design, selection of variables from the original database, literature review, analysis, and writing of the manuscript. Al SOUZA was responsible for the study design, analysis, and supervision and for writing the manuscript. C BRAGA provided valuable advice and was responsible for data analysis and the final manuscript review. M BATISTA FILHO provided valuable advice. All authors were responsible for the critical review of the manuscript.

\section{REFEREN CES}

1. Darnton-Hill I, Webb P, Harvey PW, Hunt JM, Dalmiya N, Chopra M, et al. Micronutrient deficiencies and gender: Social and economic costs. Am J Clin Nutr. 2005 [cited 2013 Feb 28]; 81(5): 1198S-1205S. Available from: <http://ajcn. nutrition.org/content/81/5/1198S.full.pdf+html>.

2. United Nation Standing Committee of Nutrition. Nutrition for improved development outcomes. Proceeding of the $5^{\text {th }}$ Report on the World Nutrition Situation. Chapter 1. Geneva: SCN; 2004 [cited 2011 Feb 10]. Available from: <http://www.unscn. org/layout/modules/resources/files/rwns5.pdf>.

3. Diaz JR, de las Cagigas A, Rodriguez R. Micronutrient deficiencies in developing and affluent countries. Eur J Clin Nutr. 2003; 57(Suppl 1):S70-S2. doi: 10.1038/sj.ejcn.1601820.

4. Ezzati M, Lopez AD, Rodgers A, Vander Hoorn S, Murray CJ. Comparative risk assessment collaborating group. Selected major risk factors and global and regional burden of disease. Lancet. 2002; 360(9343):1347-60. doi: 10.1016/j.bbr.2011.0 3.031 . 
5. Milagres RC, Nunes LC, Pinheiro-Sant'Ana HM. Vitamin A deficiency among children in Brazil and worldwide. Ciênc Saúde Colet. 2007; 12(5):1253-66. doi: 10.1590/S1413-81232007000500023.

6. Brasil. Ministério da Saúde. Pesquisa Nacional de Demografia e Saúde da Mulher e da Criança. PNDS 2006: dimensões do processo reprodutivo e da saúde da mulher. Brasília: MS; 2008 [cited 2010 mar 4]. Available from <http://www.saude.gov.br/ pnds2006>.

7. World Health Organization. Global prevalence of vitamin A deficiency in populations at risk 1995-2005. WHO Global database on vitamin A deficiency. Geneva: WHO; 2009 [cited 2010 May 15]. Available from: <http://whqlibdoc.who.int/publications/ 2009/9789241598019_eng.pdf>.

8. World Health Organization. Worldwide prevalence of anaemia 1993-2005. WHO global database on anaemia. Geneva: WHO; 2008 [cited 2010 May 15]. Available from <http://whqlibdoc.who.int/ publications/2008/9789241596657_eng.pdf>

9. Semba RD, Bloem MW. The anemia of vitamin A deficiency: Epidemiology and pathogenesis. Eur J Clin Nutr. 2002; 56(4):271-81. doi: 10.1038/sj/ejcn/ 1601320.

10. Roodenburg AJC, West CE, Hovenier R, Beynen AC. Evaluation of a two-generation rat model for vitamin A deficiency and the interrelationship with iron metabolism. Br J Nutr. 1995; 74(5):689-700. doi: 10.1079/BJN19950172.

11. Sure B, Kik M, Walker D. The effect of avitaminosis on hematopoietic function: I. Vitamin A deficiency. J Biol Chem. 1929 [cited 2013 Feb 28]; 83:375-85. Available from: <http://www.jbc.org/content/83/2/ 375.full.pdf+html>.

12. Hodges RR, Sauberlich HE, Canham JE, Wallace DL, Rucker RB, Mejia LA, et al. Hematopoietic studies in vitamin A deficiency. Am J Clin Nutr. 1978 [cited 2013 Feb 28]; 31:876-85. Available from: <http:// ajcn.nutrition.org/content/31/5/876.long $>$.

13. World Health Organization. Preventing and controlling micronutrient deficiencies in populations affected by an emergency. Geneva: WHO; 2007 [cited 2013 Feb 28]. Available from: <http://www. who.int/nutrition/publications/micronutrients/ WHO_WFP_UNICEFstatement.pdf>.

14. Brasil. Ministério da Saúde. Portaria n 730, 13 de maio 2005. Programa nacional de suplementação ferro destinado a prevenir a anemia ferropriva e dá outra providências. Brasilia: MS; 2005 [acesso 2013 fev 28]. Disponível em: <http://dtr2001.saude. gov.br/sas/PORTARIAS/Port2005/GM/GM-730. htm $>$.

15. Brasil. Ministério da Saúde. Portaria $n^{\circ} 729,13$ de maio 2005. Programa nacional de suplementação de vitamina A e de outras providencias. Brasília: MS; 2005 [acesso 2013 fev 28]. Disponível em: <http://dtr2001.saude.gov.br/sas/PORTARIAS/ Port2005/GM/GM-729.htm>.

16. Santos EN, Velarde LGC, Ferreira VA. Associação entre deficiência de vitamina A e variáveis socioeconômicas, nutricionais e obstétricas em gestantes. Ciênc Saúde Colet. 2010; 15(Supl 1):1021-30. doi: 10.1590/S1413-81232010000700008.

17. Batista-Filho M, Coordenador. III Pesquisa Estadual de Saúde e Nutrição Pernanbuco, 2006 DN/UFPE IMIP SES-PE: situação alimentar, nutricional e de saúde do Estado de Pernambuco: contexto socioeconômico e de serviços: síntese dos resultados. Recife: UFP; 2008 [acesso 2010 set 3]. Disponível em: <http://pesnpe2006.blogspot.com.br/2008/ 09/apresentao-da-pesquisa.html>.

18. Instituto Brasileiro de Geografia e Estatística. PNADPesquisa Nacional por Amostra de Domicílios: segurança alimentar. Brasília: IBGE; 2009 [acesso 2010 set 3]. Disponível em: <http://www.ibge.gov.br/ estadosat/perfil.php>.

19. Programa das Nações Unidas para Desenvolvimento. Índice de desenvolvimento humano. Brasília: PNUD; 2010 [acesso 2010 set 3]. Disponível em: <http://www.pnud.org.br>.

20. Instituto Brasileiro de Geografia e Estatística. Population Censures. Rio de Janeiro: IBGE; 2000. [acesso 2010 set 3]. Disponível em: <http://www. ibge.gov.br/english>.

21. Sommer A, Davidson FR. Assessment and control of vitamin a deficiency: The Annecy Accords. J Nutr. 2002 [cited 2013 Feb 28]; 132 (9 Suppl):2845S-2850S. Available from: <http://jn.nutrition.org/content/ 132/9/2845S.long>.

22. Furr HC, Clifford AJ, Jones AD. Analysis of apocarotenoids and retinoids by capillary gas chromatography-mass spectrometry. Methods Enzymol. 1992; 213:281-90.

23. Silva S, Batista-Filho M, Miglioni T. Prevalence and risk factors of anemia among women and their children in the State of Pernambuco. Rev Bras Epidemiol. 2008; 11(2):266-277. doi: 10.1590/S1 415-790X2008000200008.

24. Fabian C, Olinto MT, Dias-da-Costa JS, Bairros F, Nácul LC. Anemia prevalence and associated factors among adult women in São Leopoldo, Rio Grande do Sul, Brazil. Cad Saúde Pública. 2007; 23(5): 1199-205. doi: 10.1590/S0102-311X2007000500 021.

25. Dreyfuss ML, Stoltzfus RJ, Shrestha JB, Pradhan EK, LeClerq SC, Khatry SK, et al. Hookworms, malaria and vitamin A deficiency contribute to anemia and iron deficiency among pregnant women in the 
516 | MH COSTA et al.

plains of Nepal. J Nutr. 2000 [cited 2013 Feb 28]; 130(10):2527-36. Available from: <http://jn. nutrition.org/content/130/10/2527.long>

26. Zimmermann MB, Biebinger R, Rohner F, Dib A, Zeder C, Hurrell RF, et al. Vitamin A supplementation in children with poor vitamin $A$ and iron status increases erythropoietin and hemoglobin concentrations without changing total body iron. Am J Clin Nutr. 2006 [cited 2013 Feb 28]; 84(3): 580-6. Available from: <http://ajcn.nutrition.org/ content/84/3/580.long $>$.

27. Batista-Filho M, Rissin A. Nutritional transition in Brazil: Geographic and temporal trends. Cad Saúde Pública. 2003; 19(Suppl 1):s181-91. doi: 10.1590/S0 102-311X2003000700019.

28. Chagas $C B$, Ramalho $A$, Padilha $P C$, Libera BD, Saunders $C$. Reduction of vitamin A deficiency and anemia in pregnancy after implementing proposed prenatal nutritional assistance. Nutr Hosp. 2011; 26(4):843-50. doi: 10.3305/nh.2011.26.4.5053.

29. Khatib IM, Samrah SM, Zghol FM. Nutritional interventions in refugee camps on Jordan's eastern border: Assessment of status of vulnerable groups. East Mediterr Health J. 2010 [cited 2013 Feb 28]; 16(2):187-93. Available from: <http://applications. emro.who.int/emhj/N16/02/16_2_2010_0187_019 3.pdf>.

30. Angeles-Agdeppa I, Schultink W, Sastroamidjojo S, Gross R, Karyadi D. Weekly micronutrient supplementation to build iron stores in female Indonesian adolescents. Am J Clin Nutr. 1997 [acesso 2013 Feb 28]; 66(1):177-83. Available from: <http://ajcn.nutrition.org/content/66/1/177.long>.

31. Bloem MW. Interdependence of vitamin A and iron: An important association for programmes of anaemia control. Proc Nutr Soc. 1995; 54(2):501-8. doi: 10.1079/PNS19950018.

32. Amine EK, Corey J, Hegsted DM, Hayes KC. Comparative hematology during deficiencies of iron and vitamin A in the rat. J Nutr. 1970 [cited 2013 Feb 28]; 100(9):1033-40. Available from: <http:// jn.nutrition.org/content/100/9/1033.short>.

33. Suharno D, West CE, Muhilal, Logman MH, Waart FG, Karyadi D, et al. Cross-sectional study on the iron and vitamin A status of pregnant women in West Java, Indonesia. Am J Clin Nutr. 1992 [cited 2013 Feb 28]; 56(6):988-93. Available from: <http://idpas.org/pdf/353supplementation withvitaminAandlron.pdf>.

34. Zimmermann MB, Hurrell R. Nutritional iron deficiency. Lancet. 2007; 370(9586):511-20. doi: 10.1016/S0 140-6736(07)61235-5.
Received on: 20/6/2012 Final version on: 8/3/2013 Approved on: 1/7/2013 